\title{
Serum protein electrophoretic profile in diarrheic neonatal calves
}

\author{
Labrini V. Athanasiou ${ }^{1}$ (I) $\cdot$ Panagiotis Dimitrios Katsoulos ${ }^{2} \cdot$ Christos Ziogas $^{1} \cdot$ Ahmed Kassab $^{3} \cdot$ Zoe Polizopoulou $^{4}$
}

Received: 2 February 2019 / Accepted: 5 March 2019 /Published online: 12 March 2019

(C) Springer-Verlag London Ltd., part of Springer Nature 2019

\begin{abstract}
The electrophoretic profile of clinically healthy newborn calves and calves with neonatal diarrhea was compared. Blood samples were collected at 3 and 10 days of age from 11 calves that remained clinically healthy throughout the study period and 14 calves with diarrhea. A significant reduction in the gamma globulins was observed in the diarrheic calves that can be attributed to the transfer of serum immunoglobulins, to the intestinal lumen to counteract the infection. Moreover, a significant increase in the albumin was observed in this group between the sampling days that is mainly attributed to the relative reduction of the gamma globulin fraction.
\end{abstract}

Keywords Calves $\cdot$ Diarrhea $\cdot$ Electrophoresis $\cdot$ Protein

Neonatal diarrhea syndrome is the most common disease occurring in calves aged less than 15 days and a major cause of decreased productivity and economic loss to the cattle industry worldwide. The morbidity rate ranges from 25 to $50 \%$ (more commonly in poorly managed farms) and the mortality rate is between 2 and 10\% (Foster and Smith 2009).

Infectious diarrhea of newborn calves is a multifactorial disease; apart from the enterotoxinogenic Escherichia coli (ETEC) which was previously identified as the cause of the disease (Nagy and Fekete 1999), several other infectious agents such as viruses (Rotavirus, Coronavirus) and parasites (Cryptosporidium parvum) are known to infect intestinal epithelial cells, resulting in diarrhea (Cho and Yoon 2014). This, in turn, decreases the absorption of essential nutrients from milk and leads to weight loss (Tóthová et al. 2016) and dehydration (Foster and Smith 2009).

Labrini V. Athanasiou

lathan@vet.uth.gr

1 Department of Medicine, Faculty of Veterinary Medicine, School of Health Sciences, University of Thessaly, GR-43100 Karditsa, Greece

2 Clinic of Farm Animals, Faculty of Veterinary Medicine, Aristotle University of Thessaloniki, GR-54627 Thessaloniki, Greece

3 Department of Anatomy and Embryology, Faculty of Veterinary Medicine, Benha University, Moshtohor, Toukh 13736, Egypt

4 Diagnostic Laboratory, Faculty of Veterinary Medicine, Aristotle University of Thessaloniki, GR-54627 Thessaloniki, Greece
Blood proteins are likely to change during the course of the disease and their measurement is an essential part of routine biochemistry and clinical laboratory practice (Tóthová et al. 2016).

Protein electrophoresis is useful when routine investigations do not provide diagnostic information for decision making, providing the basis for further specific laboratory analyses. It is the current standard and most widely used fractionation technique for serum proteins in clinical biochemistry and molecular biology (Tóthová et al. 2018). Generally, serum protein electrophoresis is used for evaluation, diagnosis, and monitoring of a variety of diseases including chronic liver diseases, hepatic cirrhosis, hepatocellular carcinoma, $\alpha_{1}$-antitrypsin deficiency, inflammatory bowel disease, amyloidosis, and multiple myeloma (Tóthová et al. 2016). It can be also advised in patients with non-specific clinical symptoms, like depression, fever, weight loss, diarrhea, abdominal pain, or polyuria. Particularly, in ruminants, the most common use of serum protein electrophoresis is for the evaluation of the transfer of passive immunity via colostrum intake (Tóthová et al. 2016). The fractions assessed after the separation of proteins in calves are albumins, $a_{1}$-globulins, $a_{2}$-globulins, $\beta$-globulins, and $\gamma$-globulins (Tóthová et al. 2016; Tóthová et al. 2018).

There is limited information concerning the alterations that occur in the protein fractions in diarrheic calves. Such alterations could not be attributed to dehydration, protein intake differences, inadequate immunoglobulin supply, and inflammatory processes. 
The purpose of this study was to compare the electrophoretic profile of clinically healthy newborn calves and newborn calves with neonatal diarrhea.

Blood samples were collected at 3 and 10 days of age by jugular venipuncture from 25 Holstein calves of a dairy herd in Thessaly. All calves on day 3 were clinically healthy and had no sign of diarrhea. Eleven of the 25 calves remained clinically healthy throughout the study period whereas 14 of them had diarrhea (fecal score $\geq 2 ; 1=$ normal, $2=$ intermediate, $3=$ watery) (Katsoulos et al. b). At the day of sampling, all diarrheic calves had diarrhea for 3-5 days.

Serum total protein concentration was measured refractometrically with a temperature compensated refractometer (Reichert TS Meter refractometer, Model 1310400A, Reichert Scientific Instruments Buffalo, NY, USA).

Proteins were separated by electrophoresis on cellulose acetate in a Serum Electrophoresis Automated System (Minilite, Cell Diagnostic Division, Milan, Italy). The fractions assessed were albumins, $a_{1}$-globulins, $a_{2}$-globulins, $\beta$-globulins, and $\gamma$ globulins.

Data was analyzed with a statistical software (IBM SPSS Statistics 25). The significance of the differences between the percentages of protein fractions and their serum concentrations on day 3 and those on day 10 within and between each group was tested using paired-sample $t$ test. A significance level of $P \leq 0.05$ was used in all comparisons.

The significance of the differences between the percentages of protein fractions and their serum concentrations on day 3 and those on day 10 was tested using paired-sample $t$ test. The analysis was done in the whole study population as well as within each group. A significance level of $P \leq 0.05$ was used in all comparisons.

On day 10 , the percentage of albumin fraction was significantly higher $(P<0.05)$ than on day 3 in the whole study population (Table 1) and in diarrheic calves (Table 2). However, in calves that remained clinically healthy throughout the study period, no significant difference was observed $(P>0.05 ;$ Table 2). Despite these significant differences, the average serum albumin concentration was not significantly different within either group $(P>0.05$; Table 2$)$ or in the whole study population $(P>0.05$; Table 1$)$.

In contrast to albumin, the percentage, as well as the average serum concentration of gamma globulins, was significantly lower on day 10 compared to those on day 3 in diarrheic calves $(P<0.05$; Table 2$)$ and in the whole study population $(P<0.05$; Table 1). No significant difference was observed in the group of clinically healthy calves $(P>0.05$; Table 2$)$.

Concerning the other protein fractions, either their percentage or their serum concentration remained practically stable between days 3 and 10 as no significant difference was recorded $(P>0.05)$ (Tables 1 and 2).

Changes in the protein profile commonly occur as secondary symptoms in numerous diseases. The determination of
Table 1 Means \pm SE and percentage (\%) of protein fractions in total population of calves on days 3 and 10

\begin{tabular}{lll}
\hline Proteins & Day 3 & Day 10 \\
\hline Total proteins (g/dL) & $6.46 \pm 0.20$ & $6.30 \pm 0.19$ \\
Albumin (g/dL) & $3.29 \pm 0.06$ & $3.38 \pm 0.08$ \\
Albumin (\%) & $51.74 \pm 1.63^{\mathrm{a}}$ & $54.16 \pm 1.41^{\mathrm{b}}$ \\
$\mathrm{a}_{1}$-globulin (g/dL) & $0.35 \pm 0.29$ & $0.44 \pm 0.11$ \\
$\mathrm{a}_{1}$-globulin (\%) & $5.49 \pm 0.48$ & $7.35 \pm 2.06$ \\
$\mathrm{a}_{2}$-globulin (g/dL) & $0.53 \pm 0.03$ & $0.54 \pm 0.03$ \\
$\mathrm{a}_{2}$-globulin (\%) & $8.36 \pm 0.47$ & $8.72 \pm 0.59$ \\
$\beta$-globulin (g/dL) & 0.850 .08 & $1.02 \pm 0.06$ \\
$\beta$-globulin (\%) & $13.79 \pm 1.04$ & $15.16 \pm 0.51$ \\
$\gamma$-globulin (g/dL) & $1.11 \pm 0.24^{\mathrm{a}}$ & $1.49 \pm 0.21^{\mathrm{b}}$ \\
$\gamma$-globulin (\%) & $17.32 \pm 3.16^{\mathrm{a}}$ & $21.52 \pm 2.36^{\mathrm{b}}$ \\
A/G ratio & $3.52 \pm 0.49^{\mathrm{a}}$ & $4,08 \pm 0.53^{\mathrm{b}}$ \\
\hline
\end{tabular}

${ }^{\mathrm{a}, \mathrm{b}}$ Figures with different superscript letters within the same row differ significantly $(P<0.05)$

their concentration could provide useful information to the clinician towards the differential diagnosis list compilation (Bartosz and Katarzyna 2016). However, it has to be noted that the abnormalities observed in the protein profile of a patient may not only be related solely to the disease but also to physiological and to individual conditions (Elkhair and Hartmann 2014; Tóthová et al. 2014). Concerning calves, especially during the neonatal period, it must be considered that they have to adapt to different environmental factors, after the intra-uterine life, including nutrition and the result is an intense morphological, functional, and biochemical change in their organism which may be reflected to their electrophoretic profile (Piccione et al. 2009). The data concerning the alterations on the electrophoretic profile in newborn calves are limited in the available literature. It is reported (Piccione et al. 2009) that in healthy newborn calves, the concentration of albumin progressively increases, the $\alpha$-globulins decrease, and that $\beta$ - and $\gamma$-globulins remain stable during the first month of their life. However, at the same study, it was mentioned that there is no significant effect of time on the serum protein profile during the first week of life.

Total protein concentration was measured in this study by refractometry because it is easy and rapid to perform low-cost method with minimal equipment requirement. The refractometer used has been evaluated and proved to be accurate for the measurement of serum protein in cattle (Katsoulos et al. 2017a).

The average total protein concentration measured on day 3 at the present study was higher than $52 \mathrm{~g} / 1$ indicating that calves in both groups had adequate passive immunity transfer. These values remained practically stable in until day 10 even in the group of diarrheic calves despite the recorded alterations on the different fractions. This finding suggests that this 
Table 2 Means $\pm \mathrm{SE}$ and percentage $(\%)$ of protein fractions in healthy and diseased calves on days 3 and 10

\begin{tabular}{|c|c|c|c|c|}
\hline \multirow[t]{2}{*}{ Proteins } & \multicolumn{2}{|c|}{ Day 3 , mean $\pm \mathrm{SE}$} & \multicolumn{2}{|c|}{ Day 10, mean $\pm S E$} \\
\hline & Healthy & Diarrheic & Healthy & Diarrheic \\
\hline Total proteins $(\mathrm{g} / \mathrm{dL})$ & $6.16 \pm 0.33$ & $6.66 \pm 0.24$ & $5.97 \pm 0.25$ & $6.54 \pm 0.27$ \\
\hline Albumin (g/dL) & $3.37 \pm 0.14$ & $3.23 \pm 0.06$ & $3.39 \pm 0.11$ & $3.37 \pm 0.11$ \\
\hline Albumin (\%) & $55.29 \pm 2.55$ & $49.28 \pm 1.92$ & $57.27 \pm 7.15$ & $52.01 \pm 1.51$ \\
\hline $\mathrm{a}_{1}$-globulin (g/dL) & $0.30 \pm 0.35$ & $0.38 \pm 0.04$ & $0.52 \pm 0.25$ & $0.38 \pm 0.68$ \\
\hline $\mathrm{a}_{1}$-globulin $(\%)$ & $5.02 \pm 0.68$ & $5.82 \pm 0.66$ & $9.42 \pm 4.89$ & $5.92 \pm 1.05$ \\
\hline $\mathrm{a}_{2}$-globulin (g/dL) & $0.53 \pm 0.06$ & $0.53 \pm 0.39$ & $0.53 \pm 0.06$ & $0.54 \pm 0.39$ \\
\hline $\mathrm{a}_{2}$-globulin $(\%)$ & $8.58 \pm 0.76$ & $8.22 \pm 0.62$ & $9.00 \pm 1.14$ & $8.52 \pm 0.65$ \\
\hline$\beta$-globulin (g/dL) & 0.850 .08 & $1.02 \pm 0.06$ & $0.84 \pm 0.06$ & $0.95 \pm 0.06$ \\
\hline$\beta$-globulin (\%) & $13.79 \pm 1.04$ & $15.16 \pm 0.51$ & $14.08 \pm 0.59$ & $14.54 \pm 0.72$ \\
\hline$\gamma$-globulin $(\mathrm{g} / \mathrm{dL})$ & $1.11 \pm 0.24$ & $1.49 \pm 0.21^{\mathrm{a}}$ & $0.94 \pm 0.19$ & $1.28 \pm 0.18^{\mathrm{b}}$ \\
\hline$\gamma$-globulin $(\%)$ & $17.32 \pm 3.16$ & $21.52 \pm 2.36$ & $15.04 \pm 2.53$ & $19.01 \pm 20.99$ \\
\hline $\mathrm{A} / \mathrm{G}$ ratio & $4.39 \pm 0.90$ & $2.92 \pm 0.51^{\mathrm{a}}$ & $4.83 \pm 0.83$ & $3.56 \pm 0.67^{\mathrm{b}}$ \\
\hline
\end{tabular}

${ }^{\mathrm{a}, \mathrm{b}}$ Figures with different superscript letters within the same row differ significantly $(P<0.05)$ parameter is unaffected by neonatal diarrhea syndrome and its determination does not provide much information for clinical assessment of calves immediately after diarrhea episodes.

The most important finding of this study is that neonatal diarrhea syndrome is associated with significant reduction of serum gamma globulins; such a reduction was observed only in the group of diarrheic calves and concerned not only the average concentration but also the fraction of gamma globulins. This observation provides novel information concerning the pathogenesis and understanding of this syndrome as it indicates that serum immunoglobulins, which are considered as the main fraction of gamma globulins, are transferred to the intestinal lumen in order to counteract the infection. In accordance with this point of view are previous reports that diarrhea in calves is associated with a significant decline in serum immunoglobulins' concentrations (Balikci and Al 2014, Rocha et al. 2016). Furthermore, the transfer of $\mathrm{IgG}$ from the blood serum to the intestine is well defined in calves, at least as far as it concerns rotavirus antibodies (Besser et al. 1988a,b); this transfer has also been suggested as a significant mechanism of protection against rotaviral diarrhea (Besser et al. 1988a).

Similar observations regarding the presence of high antibody titers in the gut lumen that sequestrated viral particles have also been reported in canine parvoviral diarrhea (Desario et al. 2005, Kantere et al. 2015).

In accordance with this point of view are previous observations (Balikci and $\mathrm{Al} 2014$ ) that diarrhea in calves is associated with significantly lower serum Ig concentrations.

In the group of healthy calves, no alteration was recorded in gamma globulin concentration which is confirming previous findings (Piccione et al. 2009).

The significant increase in the albumin fraction in the diarrheic group between the sampling days could be attributed to the relative reduction of the gamma globulin fraction. Despite insignificant, serum albumin concentration was higher at day 10 compared with day 3 in this group. This is probably related to some degree of dehydration that these animals had due to diarrhea. The hardly identical serum albumin concentration recorded in the group of healthy calves on days 3 and 10 is in accordance with previously reported observations (Piccione et al. 2009). The other protein fractions were not significantly affected by the presence of diarrhea. The insignificant increase recorded in the al fraction of the healthy animals between days 3 and 10 is hard to explain; it is possibly associated with conditions not related to inflammatory disease (Lomborg et al. 2008).

An acute phase reaction response, although might be expected in calves with neonatal diarrhea syndrome, was not justified by the results of the present study. However, it is uncertain whether such a response, if present, is missed due to the presence of diarrhea for 3 to 5 days at the day of sampling or is masked by the dehydration that occurs and the reduction of gamma globulin concentration recorded.

The results of the present study provide evidence that neonatal diarrhea syndrome in calves is associated with significant alterations on the electrophoretic profile of serum proteins. The most important one is the significant reduction of gamma globulin concentration which is probably related to the transfer of serum immunoglobulins to the gut in order to counteract the infection. Of course, further investigation is required with repeated daily samplings even from the first day of diarrhea in order to clarify whether an acute phase response is justified in diarrheic calves and whether the observed alterations elucidate a prognostic value.

\section{Compliance with ethical standards}

Conflict of interest The authors declare that they have no conflict of interest. 
Ethical approval All applicable international, national, and/or institutional guidelines for the care and use of animals were followed.

\section{References}

Balikci E, Al M (2014) Some serum acute phase proteins and immunoglobulins concentrations in calves with rotavirus, coronavirus, E. Coli F5 and Eimeria species. Iran J Vet Res 15:397-401

Bartosz J, Katarzyna A (2016) Application of native agarose gel electrophoresis of serum proteins in veterinary diagnostics. J Vet Res 60: 501-508

Besser TE, Gay CC, McGuire TC, Evermann JF (1988a) Passive immunity to bovine rotavirus infection associated with transfer of serum antibody into the intestinal lumen. J Virol 62:2238-2242

Besser TE, McGuire TC, Gay CC, Pritchett LC (1988b) Transfer of functional immunoglobulin $\mathrm{G}(\mathrm{IgG})$ antibody into the gastrointestinal tract accounts for IgG clearance in calves. J Virol 62:2234-2237

Cho YI, Yoon KJ (2014) An overview of calf diarrhea - infectious etiology, diagnosis, and intervention. J Vet Sci 15(1):1-17

Desario C, Decaro N, Campolo M, Cavalli A, Cirone F, Elia G, Martella V, Lorusso E, Camero M, Buonavoglia C (2005) Canine parvovirus infection: which diagnostic test for virus? J Virol Methods 126:179185

Elkhair NM, Hartmann H (2014) Influence of age on serum protein capillary electrophoretic pattern in clinically healthy calves with special emphasis on serum globulins U of K. J Vet Med Anim Prod 5:30-37

Foster DM, Smith GW (2009) Pathophysiology of diarrhea in calves. Vet Clin North Am Food Anim Pract 25:13-36, xi. https://doi.org/10. 1016/j.cvfa.2008.10.013

Kantere MC, Athanasiou LV, Spyrou V, Kyriakis CS, Kontos V, Chatzopoulos DC, Tsokana CN, Billinis C (2015) Diagnostic performance of a rapid in-clinic test for the detection of canine parvovirus under different storage conditions and vaccination status. $\mathrm{J}$ Virol Methods 215-216:52-55. https://doi.org/10.1016/j.jviromet. 2015.02.012
Katsoulos PD, Athanasiou LV, Karatzia MA, Giadinis N, Karatzias H, Boscos C, Polizopoulou ZS (2017a) Comparison of biuret and refractometry methods for the serum total proteins measurement in ruminants. Vet Clin Pathol 46:620-624. https://doi.org/10.1111/ vcp. 12532

Katsoulos PD, Karatzia MA, Dovas CI, Filioussis G, Papadopoulos E, Kiossis E, Arsenopoulos K, Papadopoulos T, Boscos C, Karatzias H (2017b) Evaluation of the in-field efficacy of oregano essential oil administration on the control of neonatal diarrhea syndrome in calves. Res Vet Sci 115:478-483. https://doi.org/10.1016/j.rvsc. 2017.07.029

Lomborg SR, Nielsen LR, Heegaard PM, Jacobsen S (2008) Acute phase proteins in cattle after exposure to complex stress. Vet Res Commun 32:575-582. https://doi.org/10.1007/s11259-008-9057-7

Nagy B, Fekete PZ (1999) Enterotoxigenic Escherichia coli (ETEC) in farm animals. Vet Res 30:259-284

Piccione G, Casella S, Giannetto C, Vazzana I, Niutta PP, Giudice E (2009) Influence of age on profile of serum proteins in the calf. Acta Vet-Beograd 85:413-422

Rocha TG, Silva FDF, Bortoletto C, Silva DG, Buzinaro MG, Zafalon LF, Fagliar JJ (2016) Serum concentrations of acute phase proteins and immunoglobulins of calves with rotavirus diarrhea. Arq Bras Med Vet Zootec 68:865-872

Tóthová C, Nagy O, Kováč G (2014) Changes in the concentrations of serum protein fractions in calves with age and nutrition. Ital J Anim Sci 13:107-111

Tóthová C, Nagy O, Kováč G, Nagyová V (2016) Changes in the concentrations of serum proteins in calves during the first month of life. J Appl Anim Res 44:338-346

Tóthová C, Mihajlovičová X, Nagy OI (2018) The use of serum proteins in the laboratory diagnosis of health disorders in ruminants. IntechOpen

Publisher's note Springer Nature remains neutral with regard to jurisdictional claims in published maps and institutional affiliations. 